\title{
Analysis of the Educational and Vocational Qualification Profile of the Human Resources in the Mining and Quarrying Sector in Bulgaria
}

\author{
Monika Jaworska ${ }^{1}$, Milena Tepavicharova ${ }^{2}$, and Maral Yelubayeva ${ }^{3}$ \\ ${ }^{1}$ Społeczna Akademia Nauk, Krakow, Poland \\ ${ }^{2}$ Higher School of Security and Economics - Plovdiv, 13 Kuklensko Shose Blvd., 4004 Plovdiv \\ ${ }^{3}$ Karaganda State Medical University, Gogolja Str. 40, 100000 Karaganda, Kazakhstan
}

\begin{abstract}
Lately, considerable foreign and Bulgarian investments have been attracted to the country's quarrying industry. A number of companies are already applying the world's best practices for exploration, extraction and processing of underground resources. There are also good practices which could and should be implemented and refined to achieve the sustainable development of the extractive industry. Currently, the Bulgarian mining enterprises are operating successfully and profitably. More than 300 companies and organizations in the field of exploration, extraction and processing of underground resources and related activities and services are operating in the industry. The development of the business organizations is largely determined by the available production resources, their quality and the efficiency of their usage. One of the main resources which differs significantly from the rest is the human resource. It possesses a certain level of qualification and professional development, crucial for the productivity and prosperity. The purpose of this article is to study and analyze the educational and vocational qualification profile of the human resources employed in the quarrying industry of Bulgaria, revealing the actual possibilities for their optimal use and development for achieving higher productivity and competitiveness.
\end{abstract}

\section{Introduction}

For Bulgaria, the mining industry is particularly important. In recent years, this sector has come much closer to the EU average in terms of labor productivity. Lately, considerable foreign and Bulgarian investments have been attracted to the country's quarrying industry. A number of companies are already applying the world's best practices for exploration, extraction and processing of underground resources. There are also good practices which could and should be implemented and refined to achieve the sustainable development of the extractive industry. The realization of the general and specific strategic targets, in accordance with the European Raw Materials Initiative and the pursuit of a unified and clear state policy regarding the country's underground resources, will create prerequisites and legal guarantees for the sustainable development of the quarrying industry in Bulgaria.

Currently, the Bulgarian mining enterprises are operating successfully and profitably. More than 300 companies and organizations in the field of exploration, extraction and 
processing of underground resources and related activities and services are operating in the industry. The development of the business organizations is largely determined by the available production resources, their quality and the efficiency of their usage [1-4]. One of the main resources which differs significantly from the rest is the human resource [5-8]. It possesses a certain level of qualification and professional development, crucial for the productivity and prosperity.

The purpose of this article is to study and analyze the educational and vocational qualification profile of the human resources employed in the quarrying industry of Bulgaria, revealing the actual possibilities for their optimal use and development for achieving higher productivity and competitiveness.

\section{Materials and methods}

The effectiveness of its management plays an important role for the proper functioning of each business entity, which directly reflects on the economic results [3, 9-13]. They carry information about the combined result of skillful management work and the efficient use of the human resources [9, 14-17]. In this regard, the profit making is considered and is the main value indicator of the degree of effective management in the enterprises.

The study and analysis of the management in the companies which made a profit can open up real opportunities for optimal utilization and development of the human resources in order to achieve higher productivity and competitiveness. In this sense, the profit is seen as a function of adequate management decisions regarding the management of the human resources in the production process and in the marketing. That is why, in the current study, profit is considered to be a major indicator of the managerial effectiveness.

During the study and analysis of the status and issues of the human resources in the extractive industry in Bulgaria, 36 different in size, status and ownership business organizations were surveyed. According to their size, the researched companies are classified into three groups, namely: From 1 to 50 employees - 26.89\%; From 51 to 100 employees - 45.90\%; More than 101 employees - 27.21\%

In order to reveal the impact of the human resources on the economic performance, the surveyed business organizations are organized into two groups. The first group includes those which made a profit. The second group ranks companies which did not make a profit, but reported economic loss for the period under review. The economic result is measured by the level of the profit realized by the business organizations.

At the study and analysis of the educational and vocational qualification profile of the human resources, we used factors revealing in depth the education acquired, the professional experience and the possibilities for upgrading the professional qualification according to the Labor Code and the internal regulations in the business organizations. (Table 1).

Table 1. Factors for analysis of the professional development and qualification of the human resources in the business organizations.

\begin{tabular}{|l|l|l|l|}
\hline \multicolumn{4}{|c|}{ Educational and professional-qualification profile of managerial staff } \\
\hline 1.Education & 2. Professional & 3. Professional & 4. Learning and use of \\
a/ secondary general level; & experience & specialization & foreign languages \\
b/ vocational secondary & a/ up to $15 \mathrm{yrs.}$ & a/ at home; & a/English; b/French; \\
education; & b/ from 16 to 35 & b/ abroad. & c/German; d/Russian; \\
c/ higher education - bachelor's; & yrs.; & e/Other languages \\
d/ higher education - master's; & c/ above 36 yrs. & \\
\hline \multicolumn{3}{|c|}{ Educational and professional-qualification profile of subordinate staff } \\
\hline 1. Education & 2. Professional experience \\
a/ elementary educational level; & a/ up to 15 yrs.; \\
\hline
\end{tabular}




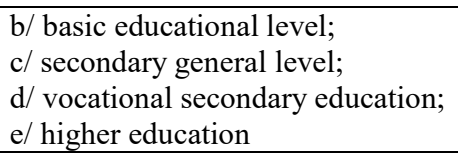

The factors considered are differentiated for the managerial and the subordinate staff. Under managerial staff, we list all managers from different levels of management who have the power to make and put in action management decisions without necessarily agreeing with managers from other levels of authority. The subordinate staff includes all employees of the surveyed enterprises who do not have the authority to make management decisions, but must coordinate their actions with the decision-maker for the specific activity.

For the purposes of the economic and managerial analysis hereby performed, the surveyed companies shall also be considered according to their organizational and economic structure, namely:

- Sole Traders /SL/ (8\%) - These are mostly small in size businesses. The main part of their production is intended for the local markets.

- Capital companies - these are Sole-Owner Limited Liability Companies (Ltd.), which are $34 \%$ of the total surveyed, Limited Liability Companies (LLC), whose share is $37 \%$ and Joint Stock Companies (JSC), with a share of $21 \%$.

The research covers the period between 2017 - 2019. The final analysis data represent the averages of the three years of the survey. The data and information are collected through direct contacts, completion of specially developed for the purpose of the analysis reports, tables, company documentation, etc. The interview method is used to clarify the data and information. Of the 36 companies surveyed, $86.11 \%$ made a profit for the period and $13.89 \%$ reported an economic loss.

At the statistical data processing we used the descriptive analysis method - average values $(\bar{x})$, standard error of average value $(\mu)$, median $(\mathrm{Me})$, mode $(\mathrm{Mo})$, standard deviation $(\mathrm{Sd})$, minimum $(\mathrm{min})$ and maximum $(\max )$ values. For the data processing and analysis we applied the statistical package SPSS 13.0 and Microsoft Office (Word, Excel, Power Point), too.

\section{Results and discussion}

Analysis of the educational and vocational qualification profile of the management staff in the mining and quarrying industry in Bulgaria.

In order to determine the impact of the educational and vocational qualification profile of the management staff, we analyzed the acquired education, professional experience and the opportunities for upgrading the professional qualification.

The information on the results of the surveyed business organizations for the period 2017 - 2019 is presented in Table 2. In the analysis of the factor Education in the business organizations which have achieved positive economic results, the managers with higher education are just over half - 55.28\%. Of these, $38.78 \%$ hold a master's degree and $16.5 \%$ a bachelor's. The holders of secondary education are $44.72 \%$, of whom only $24.49 \%$ have secondary specialized education. It should be noted hereby that the unfavorable working conditions make this sector unattractive for management personnel with a particularly high level of education.

The results of the loss-reporting companies during the research period also provoke interest. The managers with higher education are only $19.23 \%$. At the same time, those with secondary education are $80.77 \%$. Most of them have secondary education without specialization $(42.31 \%)$. The aforementioned indicates that the level of education of the management staff of the loss-making organizations is significantly lower than that of those 
occupying good economic positions. Therefore, a high level of educational and vocational training is particularly important for achieving positive economic results.

Table 2. Status of the educational and vocational qualification profile of the management staff.

\begin{tabular}{|l|c|c|c|c|c|}
\hline \multirow{2}{*}{ Factors } & \multicolumn{2}{|c|}{$\begin{array}{c}\text { Companies } \\
\text { which made a } \\
\text { profit }\end{array}$} & $\begin{array}{c}\text { Companies } \\
\text { which declared } \\
\text { a loss }\end{array}$ & $\begin{array}{c}\text { Deviation from } \\
\text { loss- to profit- } \\
\text { making companies }\end{array}$ \\
\cline { 2 - 6 } & $\begin{array}{c}\text { Number. } \\
\overline{\boldsymbol{x}}\end{array}$ & $\mathbf{\%}$ & $\begin{array}{c}\text { Number. } \\
\overline{\boldsymbol{x}}\end{array}$ & $\mathbf{\%}$ & $\%$ \\
\hline Management staff & & & & & \\
\hline 1. Higher education - master's; & 2.28 & 38.78 & 0.56 & 17.31 & 24.56 \\
\hline 2. Higher education - bachelor's; & 0.97 & 16.50 & 0.06 & 1.92 & 6.19 \\
\hline 3. Vocational secondary education; & 1.44 & 24.49 & 1.26 & 38.46 & 87.50 \\
\hline 4. Secondary general level; & 1.19 & 20.23 & 1.37 & 42.31 & 31.09 \\
\hline 5. Professional experience up to 15 & 2.16 & 36.73 & 1.25 & 38.46 & 57.87 \\
\hline $\begin{array}{l}\text { 6. Professional experience from 16 to } \\
\text { 35 yrs. }\end{array}$ & 2.43 & 41.33 & 1.06 & 32.69 & 43.62 \\
\hline 7. Professional experience above 36 y & 1.29 & 21.94 & 0.94 & 28.85 & 72.87 \\
\hline 8. Professional specialization & 0.95 & 16.16 & 0.00 & 0.00 & 0.00 \\
\hline at home; & 0.6 & 63.16 & 0.00 & 0.00 & 0.00 \\
\hline abroad. & 0.35 & 36.84 & 0.00 & 0.00 & 0.00 \\
\hline $\begin{array}{l}\text { 10. Learning and use of foreign } \\
\text { languages }\end{array}$ & 3.36 & 57.14 & 0.50 & 15.38 & 14.88 \\
\hline English; & 1.39 & 41.37 & 0.19 & 37.5 & 13.67 \\
\hline French; & 0.28 & 8.33 & 0.00 & 0.00 & 0.00 \\
\hline German; & 0.32 & 9.52 & 0.12 & 25.0 & 37.50 \\
\hline Russian; & 0.47 & 13.99 & 0.13 & 25.0 & 27.66 \\
\hline other languages. & 0.90 & 26.79 & 0.06 & 12.5 & 6.67 \\
\hline & & & & & \\
\hline
\end{tabular}

The analysis of the educational and vocational qualification profile of the management personnel also examines the factor of Professional Experience. The longer professional experience implies greater quantity and higher quality of acquired knowledge and utilized opportunities for its application. In terms of this factor, the managers with experience in the specialty from 16 to 35 years claim the largest share in the organizations which made a profit $/ 41.33 \% /$. The close shares of the other two groups - those with acquired qualification experience up to 15 years - $36.73 \%$ and with vocational experience of over 56 years $21.94 \%$, indicate that there is a possibility of continuity in the transfer of knowledge and skills in practice.

In the companies which declared loss, the highest share is attributed to managers with experience in the specialty of up to 15 years $/ 38.46 \% /$. The other two groups demonstrate similar share distributions. The managers with vocational experience from 16 to 35 years are $32.69 \%$, and those with experience in the specialty of over 36 years $-28.85 \%$. The negative results of these companies indicate that the managers' lack of professional experience directly affects the economic situation of the organizations surveyed.

The analysis of the Professional Specialization factor clarifies the reasons for the differences in the economic status of the quarrying companies. In those which made a profit, $16.16 \%$ of the management staff has specialized in the country and/ or abroad. The majority $(63.16 \%)$ have specialized at home, but the percentage of those specialized abroad is not at all small $-36.84 \%$. At the same time, companies with a loss for the period lack managers with acquired specialization. This leads to the conclusion that enhancing the qualification and improving the knowledge and experience with specializations in the country and/ or abroad, has a strong positive impact on the economic situation of the mining industry enterprises. 
The development of the extractive industries requires continuous improvement and selfimprovement of the expertise of the managerial staff and also implementation of best practices and innovative solutions in the industry on a global scale. This largely depends on the ability to communicate and the fluent use of foreign languages. Therefore, the factor Multilingual Abilities is especially important in analyzing the impact of the human resources on the financial performance of the business organizations.

A study on the profit-making organizations shows that more than half of their managers $(57.14 \%$ ) can use a foreign language. Of these, $41.37 \%$ speak English, $9.52 \%$ of the management staff speak German, while $8.33 \%$ speak French. The Russian language is used by $13.99 \%$, and $26.79 \%$ of the managers stated that they used other languages, both in their daily life and in their work. In the loss-reporting companies, the proportion of bilingual managers is significantly lower $-15.38 \%$, which reflects on the ultimate economic performance. The use of foreign languages enables easy access to the international scientific achievements in the quarrying industry. This helps to constantly update the expertise of the managers. The adoption of state-of-the-art techniques and technologies in the production leads to positive economic results.

With regard to the characteristics of the types of business organizations according to their organizational and economic structure, the study showed (Figure 1):

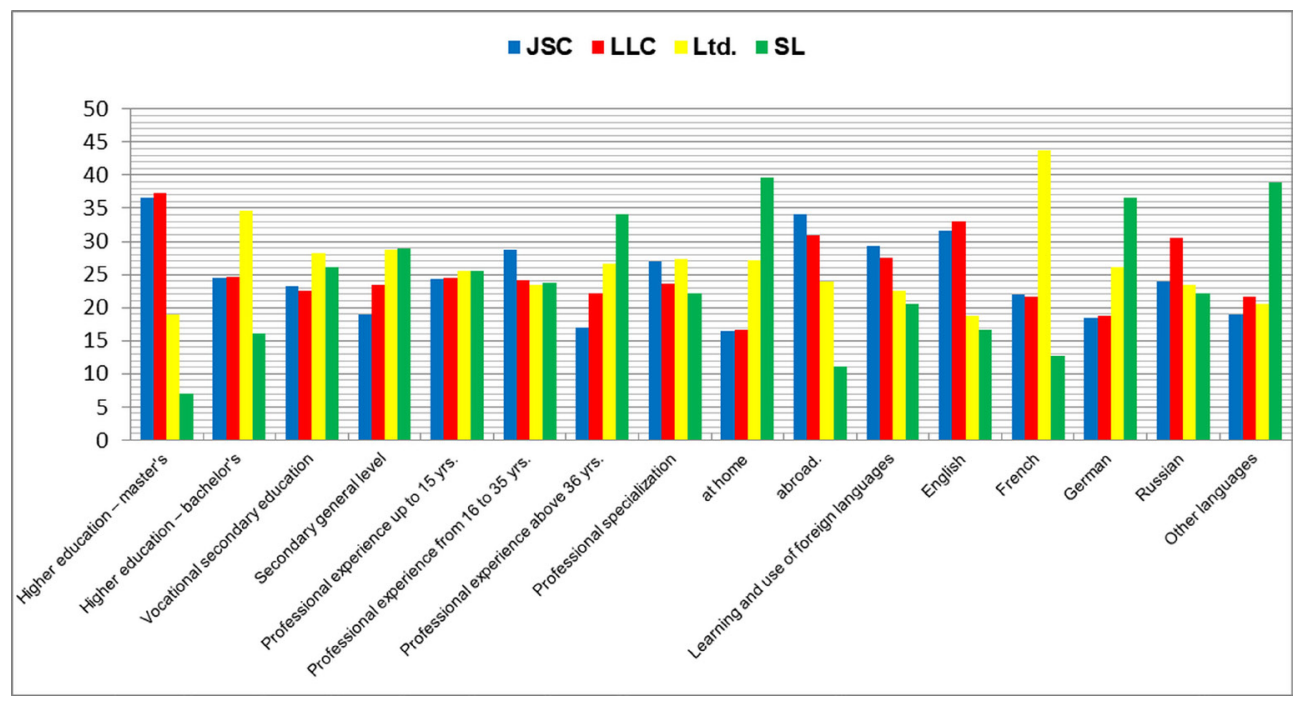

Fig. 1. Relative share of the different types of business organizations according to their organizational and economic status.

- The highest relative share of managers with higher education is observed in the capital companies. At JSC and LLC, the majority of the management personnel hold a Master's degree, while at Ltd., the larger part of them have a Bachelor's degree.

- The SL rely mainly on managers with a Bachelor's degree, as well as on specialists with secondary education.

- In terms of professional experience, the data show a relatively proportionate distribution of the shares in the different groups.

- The SL managers specialized mainly in the country, while the specializations abroad are a priority for those managing the JSC and LLC.

- In SL, the highest relative share is recorded in terms of command and use of German and other languages. At Ltd., the managers who communicate freely in French account for relatively the largest number. The highest relative share of English-speaking managers is recorded in the group of LLC and JSC. 
The analysis of the educational and vocational qualification profile of the management staff demonstrates that the improvement of the qualification and the enhancement of knowledge and experience through specializations in the country and/ or abroad have a strong positive impact on the economic situation of the commercial organizations in the Bulgarian extractive industry. The use of foreign languages enables the easier access to international scientific achievements. In this way, the continuous updating and sophistication of the knowledge of the business managers is ensured.

Analysis of the educational and vocational qualification profile of the subordinate staff in the mining and quarrying industry in Bulgaria.

In order to determine the impact of the educational and vocational qualification profile of the subordinate members, we analyzed the level of education and the professional experience gained over the years. (Table 3 ).

Table 3. Status of the educational and vocational qualification profile of the subordinate staff.

\begin{tabular}{|l|c|c|c|c|c|}
\hline \multirow{2}{*}{ Factors } & \multicolumn{2}{|c|}{$\begin{array}{c}\text { Companies } \\
\text { which made a } \\
\text { profit }\end{array}$} & \multicolumn{2}{c|}{$\begin{array}{c}\text { Companies } \\
\text { which } \\
\text { declared a loss }\end{array}$} & $\begin{array}{c}\text { Deviation from } \\
\text { loss- to profit- } \\
\text { making companies }\end{array}$ \\
\cline { 2 - 6 } & $\begin{array}{c}\text { Number, } \\
\overline{\boldsymbol{x}}\end{array}$ & $\mathbf{\%}$ & $\begin{array}{c}\text { Number, } \\
\overline{\boldsymbol{x}}\end{array}$ & $\mathbf{\%}$ & $\mathbf{\%}$ \\
\hline Executive staff & & & & & \\
\hline 1. Higher education; & 0.47 & 2.15 & 0.00 & 0.00 & 0.00 \\
\hline 2. Vocational secondary education; & 3.29 & 15.04 & 0.63 & 5.46 & 19.14 \\
\hline 3. Secondary general level; & 11.53 & 52.70 & 5.68 & 49.73 & 49.26 \\
\hline 4. Basic educational level; & 5.44 & 24.90 & 3.75 & 32.79 & 68.93 \\
\hline 5. Elementary educational level; & 1.14 & 5.21 & 1.37 & 12.02 & 120.18 \\
\hline 6. Professional experience up to 15 & 5.96 & 27.20 & 2.43 & 21.31 & 40.77 \\
\hline $\begin{array}{l}\text { 7. Professional experience from 16 to } \\
\text { 35 yrs.; }\end{array}$ & 8.88 & 40.60 & 4.44 & 38.80 & 50.00 \\
\hline 8. Professional experience above 36 & 7.03 & 32.20 & 4.56 & 39.89 & 64.86 \\
\hline
\end{tabular}

The analysis of the data reveals that almost one-third of the employees in the surveyed organizations which made a profit possess lower than average education. In the lossreporting companies, the share of workers with primary and elementary education is even higher $(32.79 \%$ with primary and $12.02 \%$ with elementary education). This displays the extremely low level of education of the subordinate staff in the studied mining organizations in Bulgaria. What is more, even the longer professional experience cannot compensate for the lack of knowledge gained through education. This issue has a negative influence on the quality of the human resources in the industry, which also affects the lower production and economic performance in the sector.

The relative share distribution of the types of business entities according to their organizational and economic structure under the Educational and Vocational Qualification Profile criterion of the subordinate staff is presented in Figure 2. There is a high level of education among the subordinate employees in the organizations of JSC and LLC. In them, the share of personnel with tertiary education is highest and the number of those with primary and elementary education is relatively low. 


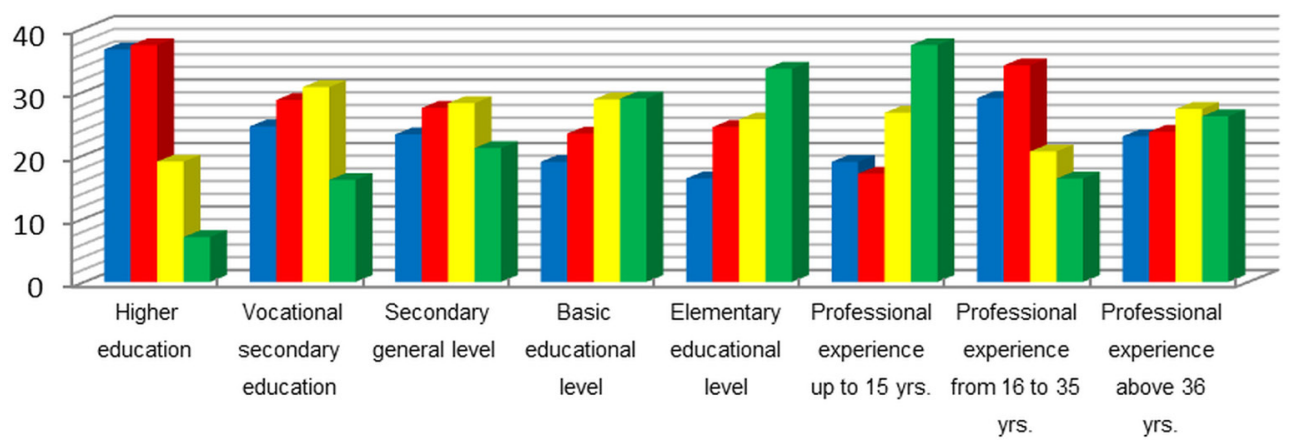

Fig. 2. Relative share of the different types of business organizations according to their organizational and economic status.

In the other two groups, the level of the subordinate staff's education is relatively low. In some enterprises with predominant manual labor and older equipment and technologies, the low educational level is possible, to some extent, to be compensated for with longer experience in the field.

In order to achieve higher economic results, it is necessary to constantly introduce innovations in the production activity, as well as to automate the work processes, which requires a high educational and professional level of the subordinates in the companies operating in the extractive industry in Bulgaria.

\section{Conclusions}

The higher educational and vocational training is of crucial significance for achieving positive economic results. The enhancing of the qualification and broadening of the knowledge and experience through additional specializations in the country and/ or abroad of the management personnel should become a mandatory practice in the commercial organizations in the quarrying industry in Bulgaria. This is an essential factor for the effective management and positive production and economic results.

Enriching the vocational training and qualification of the employees in the quarrying industry can lead to higher productivity and more stable and guaranteed income. From this point of view, the investments in human capital will increase individual productivity and hence the economic performance of the businesses.

\section{References}

1. A. Zahariev, M. Zveryakov, S. Prodanov, G. Zaharieva, P. Angelov, S. Zarkova, M. Petrova, Entrepreneurship and Sustainability Issues, 7:3, 2382-2393 (2020)

2. V. Koval, G. Duginets, O. Plekhanova, A. Antonov, M. Petrova, Entrepreneurship and Sustainability, 6:4, 1922-1937 (2019)

3. O. Baklanova, M. Petrova, V. Koval, Economic Studies, 29:1, 68-91 (2020)

4. T. Odinokova, M. Bozhinova, M. Petrova, E3S Web Conf., 41, 04015 (2018)

5. K. Mussapirov, J. Djalkibaev, G. Kurenkeyeva, A. Kadirbergenova, M. Petrova, L. Zhakypbek, Entrepreneurship and Sustainability Issues, 7:2, 1480-1495 (2019)

6. V. Jarmusevica, D. Ilisko, J. Badjanova, V. Jukss, M. Petrova, SGEM, 5:3, 645-652 (2019) 
7. N. Kurmanov, M. Petrova, S. Suleimenova, E3S Web Conf., 105, 04045 (2019)

8. A. Zagorodnya, N. Dichek, N. Chobitko, M. Voznyk, L. Honchar, M. Petrova, International Journal of Higher Education, 9:3, 139-144 (2020)

9. I. Kolechkina, I. Verchagina, E. Eltsova, M. Petrova, E3S Web Conf., 134, 02004 (2019)

10. Sv. Labunska, M. Petrova, O. Prokopishyna, Economic Annals - XXI, 165:5-6, 13-18 (2017)

11. Yu. Dyachenko, N. Nenkov, M. Petrova, I. Skarga-Bandurova, O. Soloviov, Biologically Inspired Cognitive Architectures, 26, 130-135 (2018)

12. R. Pukala, M. Petrova, E3S Web Conf., 105, 04034 (2019)

13. K. Naama, European Journal of Science and Research, 2, 92-100 (2018)

14. K. Naama, Economic Studies, 19:1, 118-149 (2010)

15. R. Vazov, Inovative Approaches to Insurance Company Cash-Flow Management (VUZF Publishing House "St. Grigorii Bogoslov", Sofia, 2019)

16. M. Tepavicharova, L. Dikova, V. Zahars, E3S Web Conf., 105, 04029 (2019)

17. L. Levashova Problemy zarzadzania kapitałem ludzkim - wyzwania współczesności (Wydawnictwo L\&J Techtrading sp. z o.o., Warszawa, 2010) 